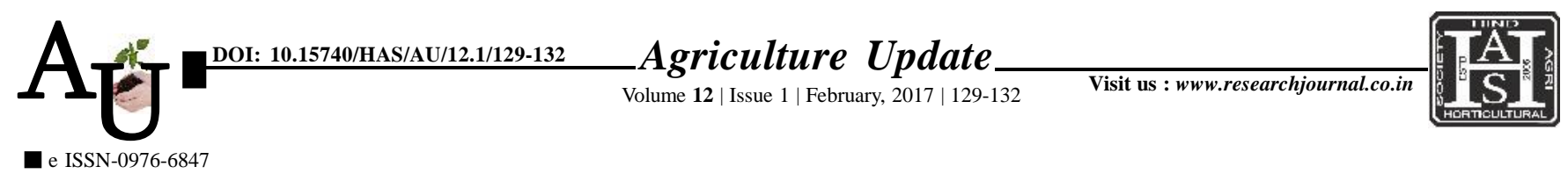

\title{
Research Article: Association between level of knowledge of rice cultivation technology with the selected independent variables
}

\section{DWARKA PRASAD, L.S. BARETH, DEEPAK CHATURVEDI, AMIT KUMAR KESHRI AND HEMANT KUMAR JHINGONIYA}

Article Chronicle:

Received :

12.12.2016;

Revised :

09.01.2017;

Accepted :

16.01.2017

KeY Words:

Knowledge,

Association,

Respondent, Beneficiary, Nonbeneficiary

Author for correspondence :

\section{DEEPAK CHATURVEDI}

Directorate of

Extension Education,

S.K. Rajasthan

Agricultural University,

BIKANER (RAJASTHAN)

INDIA

Email:dpjangir02@gmail.

com

See end of the article for authors' affiliations
SUMMARY : The study was conducted in Hanumangarh district of Rajasthan as the district had highest area and production of rice crop as compared to other district of Sri Ganganagar region. Three Panchayat samities were selected from district having highest area under rice crop and demonstrations were conducted under MMA about improved package of practices of rice crop. The Department of Agriculture, Govt. of Rajasthan has conducted demonstration on improved package of practices of rice cultivation technology in these twelve villages under MMA scheme. All the respondents who had participated in demonstration on improved package of practices of rice cultivation technology were called as beneficiary. Equal numbers of non- beneficiary farmers, who did not participate in the demonstrations, from each selected villages were also selected to make the study comparable. In all 210 respondents were included for the study purpose out of which 50 per cent i.e. 105 were beneficiaries and remaining 105 non-beneficiaries were rice growers. Data were collected by personal interview method. Various statistical measures viz., chi- square test, ' $z$ ' test, ' $t$ ' test and Spearman's rank correlation tests were used for analyzing the data. There was significant association between education, size of land holding, annual income, social participation and sources of information utilized with knowledge level of the farmers. The age, caste, family type and family size of rice growers were non-significantly associated with the knowledge level of the farmers.

How to cite this article : Prasad, Dwarka, Bareth, L.S., Chaturvedi, Deepak, Keshri, Amit Kumar and Jhingoniya, Hemant Kumar (2017). Association between level of knowledge of rice cultivation technology with the selected independent variables. Agric. Update, 12(1): 129-132; DOI : 10.15740/HAS/AU/12.1/129-132. 